\title{
Fundamentals of Biochemical Pharmacology
}

\section{Edited by Z. M. Bacq}

Covers the metabolism of drugs and their mode of action at the biochemical/biophysical level. About half the book is devoted to describing experimental technique, the remainder to current knowledge, each chapter being contributed by an expert in that field.

644 pages $\$ 10.00$ hard cover

\section{Human Anti-Human Gammaglobulins}

Their Specificity and Function

Edited by R. Grubb and G. Samuelsson

This, the first volume dealing specifically and extensively with human anti-human gammaglobulins, contains edited discussions and 28 papers by international authorities. Provides invaluable information for readers at the professional and investigative level.

256 pages 66.00 hard cover

\section{Human Afflictions and Chromosomal Aberrations}

\section{R. Turpin and J. Lejeune}

Deals with human disorders which have been shown to be due to chromosomal aberrations. All modern work which is developing rapidly with the advent of new techniques is covered and these findings have opened up a hitherto closed chapter in human pathology and have encouraged the development of a new branch of medicine.

406 pages 68.00 hard cover

\section{The Transmission of Schizophrenia}

Edited by C. Rosenthal and S. S. Kety

This volume contains the Proceedings of the Second Research Conference of the Foundations' Fund for Research in Psychiatry and the twenty-eight contributors represent leaders in the field throughout the world. The book concentrates upon data and evidence rather than theory, and constitutes a definitive summary of current knowledge and the data upon which it is based.

448 pages $\mathrm{E} 6.30$ hard cover

\section{Serendipity in St Helena}

A Genetical and Medical Study of an isolated community

\section{Shine}

"This charming and extremely readable book combines in its 200 pages a vivid personal account of a unique community."

British Medical Journal

\section{2 pages $\quad$ 3.75 hard cover}

G 101
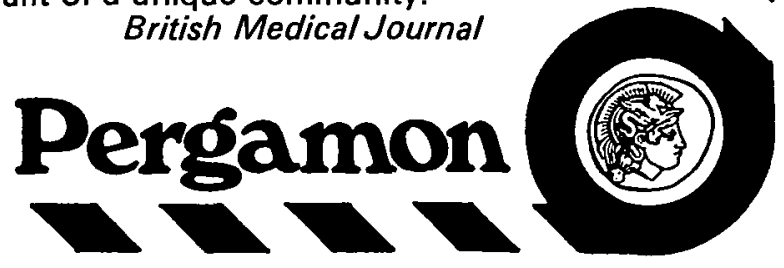

(i) 


\section{Mendelian}

\section{Inheritance}

\section{in Man}

Catalogs of Autosomal Dominant, Autosomal Recessive, and X-linked Phenotypes

\section{Third Edition}

Victor A. McKusick Dr. McKusick's highly praised encyclopedia of genetic disorders and Mendelian traits in man has now been updated and considerably enlarged. Latest computer techniques were used in assembling and revising this ever-growing body of information. A Science review of the first edition stated, "This book should be in the library of all biologists, medical or other, who are interested in genetics."

$\$ 17.50$

Man, Mind, and Heredity Selected Papers of Eliot Slater on Psychiatry and Genetics Edited by James Shields and Irving 1. Gottesman $\$ 15.00$

Epidermolysis Bullosa A Clinical, Genetic, and Epidemiological Study Tobias Gedde-Dahl, Jr. $\$ 20.001$

Development of the Genital System and Male Pseudohermaphroditism Jan E. Firásek Edited by.M. Michael Cohen, Fr. $\$ 12.00$

Progress in Human Behavior Genetics Recent Reports on Genetic Syndromes, Twin Studies, and Statistical Advances Edited by Steven G. Vandenberg

$\$ 12.50$

Haldane and Modern Biology Edited by $K . R$. Dronmraju $\$ 10.95$

Proceedings of the Third International Congress of Human Genetics Edited by James $F$. Crow and James V. Neel

\section{THE JOHNS}

\section{HOPKINS PRESS}

Baltimore, Maryland 21218

(ii) 


\section{GENETICAL \\ RESEARCH}

EDITORIAL BOARD

C. H. WADDINGTON (Chairman)

CHARLOTTE AUERBACH J.R. S. FINCHAM

W. HAYES MARYF.LYON

R. RILEY A. ROBERTSON

EXEOUTIVE EDITOR

E. C. R. REEVE

ASSISTANT EXEOUTIVE EDITOR

J. O. BISHOP

\section{Volume 18. 1971}

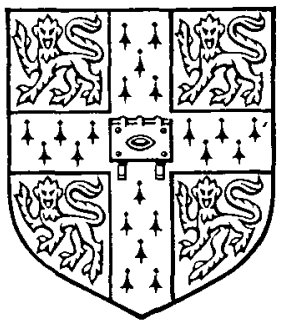

CAMBRIDGE

AT THE UNIVERSITY PRESS

1971 
PUBLISHED BY

THE SYNDICS OF THE CAMBRIDGE UNIVERSITY PRESS

Bentley House, 200 Euston Road, London NW1 2DB

American Branch: 32 East 57th Street, New York, N.Y. 10022

Printed in Great Britain at the University Printing House, Cambridge 


\section{CONTENTS}

\section{No. 1 (August 1971)}

McNew, Ronald W. and BeLL, A. E. The nature of the purebredcrossbred genetic covariance

Hedges, R. W. Transduction mechanisms of bacteriophage $\epsilon^{\mathbf{1 5}}$. I. General properties of the system

Hedges, R. W. Transduction mechanisms of bacteriophage $\epsilon^{15}$. II. Isolation of a bacteriophage related to $\epsilon^{\mathbf{1 5}}$

HEDGES, R. W. Transduction mechanisms of bacteriophage $\epsilon^{15}$. III. A new class of mutations affecting the conversion of Salmonella anatum by bacteriophage $\epsilon^{15}$

PouRquiÉ, J. and Hestot, H. Utilization and interconversions of purine derivatives in the fission yeast Schizosaccharomyces pombe

OISHI, KUGao. Spirochaete-mediated abnormal sex-ratio (SR) condition in Drosophila: A second virus associated with spirochaetes and its use in the study of the SR condition

Mitra, R. and Bhatia, C. R. Isoenzymes and polyploidy. I. Qualitative and quantitative isoenzyme studies in the Triticinae

Johnson, D. R. Genes and genotypes affecting embryonic fluid relations in the mouse

MaRUYAMA, TAKEo. An invariant property of a structured population

Putrament, Aleksandra. Recombination and chromosome structure in eukaryotes

Sved, J. A. An estimate of heterosis in Drosophila melanogaster

Starling, David and Randall, Sir John. The flagella of temporary dikaryons of Chlamydomonas reinhardii

Grimes, Gary W. and Preer, John, R. JR. Further observations on the correlation between kappa and phage-like particles in paramecium

VYSE, E. R. and SANG, J. H. A purine and pyrimidine requiring mutant of Drosophila melanogaster

\section{No. 2 (October 1971)}

Kimura, Motoo and Maruyama, Takeo. Pattern of neutral polymosphism in a geographically structured population

Sermonti, G., Puglia, A. Maria and Ficarra, Giuseppina. The time course of recombinant production in Streptomyces coelicolor

Thornton, R.J. and Johnston, J. R. Rates of spontaneous mitotic recombination in Saccharomyces Cerevisiae 
North, J ditions for their production and the genetics of the alkaline phosphatase

page 153

UPSHall, A. Phenotypic specificity of aneuploid states in Aspergillus nidulans

Pinney, R. J. and Smith, J. T. R-Factor elimination by thymine starvation

Johnston, J. R. Genetic analysis of spontaneous half-sectored colonies of Saccharomyces cerevisiae

Dunn, N. W. and Holloway, B. W. Pleiotropy of $p$-fluorophenylalanineresistant and antibiotic hypersensitive mutants of Pseudomonas aeruginosa

Paszewski, A., Prażmo, W. and Jaszczuk, E. Multiple recombinational events within the $84 \mathrm{~W}$ locus of Ascobolus immersus

Searle, A. G., Ford, C. E. and Brechey, C. V. Meiotic disjunction in mouse translocations and the determination of centromere position

Gale, Michael D. and Flavelu, Richard B. The genetic control of anthocyanin biosynthesis by homoeologous chromosomes in wheat

\section{No. 3 (December 1971)}

LatTer, B. D. H. Quantitative genetic analysis in Phalaris tuberosa. III. Maternal effects on seedling growth and development

LAMB, B. C. Some details and effects of the premeiotic controls of recombination frequencies in Neurospora crassa

Sharat Chandra, H. Inactivation of whole chromosomes in mammals and coccids: some comparisons

Oнта, Tомоко. Associative overdominance caused by linked detrimental mutations

Foster, T. J. and Howe, T. G. B. Recombination and complementation between $\mathrm{R}$ factors in Escherichia coli $\mathrm{K} 12$

DAY, A. W. and Jones, J.K. $p$-Fluorophenylalanine-induced mitotic haploidization in Ustilago violacea

WaLL, A. M., RILEY, RaLPH and Chapman, ViCtor. Wheat mutants permitting homoeologous meiotic chromosome pairing

WaLl, A. M., RILEY, Ralph and GaLe, M. D. The position of a locus on chromosome 5B of Triticum aestivum affecting homoeologous meiotic pairing

Moore, David and Stewart, George R. Mutants of Coprinus lagopus selected for resistance to 2-Deoxy-D-glucose

Hedges, R. W. A simple technique for the identification of chain termination suppressor mutants in species of Salmonella 


\section{GENETICAL RESEARCH}

VOLUME 18, NUMBER 3, DECEMBER 1971

\section{CONTENTS}

LAtTer, B. D. H. Quantitative genetic analysis in Phalaris tuberosa.

III. Maternal effects on seedling growth and development

Lа м в, в. с. Some details and effects of the premeiotic controls of recombination frequencies in Neurospora crassa

SHARAT CHANDRA, H. Inactivation of whole chromosomes in mammals and coccids: some comparisons

онта, томоко. Associative overdominance caused by linked detrimental mutations

FOSTER, T. J. and HоWE, T. G. B. Recombination and complementation between R factors in Escherichia coli $\mathrm{K} 12$

DAY, A. w. and JONES, J. K. $p$-Fluorophenylalanine-induced mitotic haploidization in Ustilago violacea

WALL, A. M., RILEY, RALPH and OHAPMAN, vICTOR. Wheat mutants permitting homoeologous meiotic chromosome pairing

WALL, A. M., RILEY, RALPH and GALE, M. D. The position of a locus on chromosome 5B of Triticum aestivum affecting homoeologous meiotic pairing

MOORE, DAVID and STEWART, GEORGE R. Mutants of Coprinus lagopus selected for resistance to 2-deoxy-D-glucose

HEDGES, R. W. A simple technique for the identification of chain termination suppressor mutants in species of Salmonella

\section{CAMBRIDGE UNIVERSITY PRESS}

Bentley House, 200 Euston Road, London NW 12 DB

American Branch: 32 East 57th Street, New York, N.Y.10022

SubSCRIPTion $£ 5$ net (U.S.A. \$16.50) per volume

SiNGLE PARTS $£ 2.30$ net (U.S.A. \$7.00) 